\title{
Managing business model renewal
}

\section{Christian Sandström*}

Technology Management and Economics, Chalmers University of Technology,

Vera Sandbergs Allé 8, Göteborg SE-412 96, Sweden

E-mail: christian.sandstrom@chalmers.se

*Corresponding author

\section{Ralf-Geert Osborne}

Department of Technology Policy Analysis and Management, Section of Technology Strategy and Entrepreneurship, Delft University of Technology, Jaffalaan 5, BX Delft 2628, The Netherlands E-mail: ralf.osborne@gmail.com

\begin{abstract}
It is well-documented that firms often need to change their business model when introducing a new product, but more knowledge is needed regarding why they struggle when trying to do so. This paper explores the challenges related to renewing an established business model. Drawing upon a case study and industrial network theory, we argue that business models are difficult to change because they are based upon interdependence throughout a system of interrelated actors. Firms are interconnected with actors beyond its boundaries and thus, only a limited control can be imposed. Our findings also suggest that firms can change their business models by identifying critical actors and by aligning incentives throughout their network.
\end{abstract}

Keywords: innovation; discontinuous; systems; business model; interdependence; disruptive.

Reference to this paper should be made as follows: Sandström, C. and Osborne, R-G. (2011) 'Managing business model renewal', Int. J. Business and Systems Research, Vol. 5, No. 5, pp.461-474.

Biographical notes: Christian Sandström is a PhD Candidate at the Center for Business Innovation at Chalmers University of Technology, Gothenburg Sweden. He holds an MSc in Industrial Engineering and an MSc in Economics. His research interests concern technological change and the challenges they imply for incumbent firms.

Ralf-Geert Osborne works as a Technical Assistant at Schindler in Luzern and works with organisational change and data management throughout the product lifecycle. He holds an MSc in Management of Technology, from Delft University of Technology in The Netherlands. 


\section{Introduction}

For many decades, scholars have primarily looked inside the firm (e.g. Tushman and Anderson, 1986) in order to explain why established companies tend to encounter difficulties in the face of technological shifts. Christensen (1997) brought a different perspective upon this issue by looking at the firm's external environment and argued that those technologies which initially underperform according to the demands of mainstream customers tend to be problematic for established firms. Christensen and Raynor (2003) claimed that there are two forms of disruptive technologies, namely those which emerge in low-end segments and in new markets.

Over the last decade, business models have received increased attention, both by scholars and by practitioners. This construct focuses more explicitly on value creation and appropriation than other frameworks in strategic management (Teece, 2010). It is often argued that innovations of a more radical or discontinuous nature need a new business model in order to succeed in the market (Christensen, 2006). New business models can also help firms to appropriate the returns from a new product and to compete in mature industries.

While the concept is clearly of great importance, more work is needed regarding the challenges related to business model renewal. Many authors have pointed out that firms often fail to change their business models (Chesbrough and Rosenbloom, 2002), but these difficulties need to be better understood, both theoretically and empirically.

This paper explores the challenges related to business model innovation. It seeks to create a better understanding of why firms struggle to renew their business models, despite the increased awareness of the imperative to do so. This paper also aims to point out some guidelines for how firms can go about when trying to change their business models. This is done by drawing upon the literature on industrial networks and by presenting an illustrative case study. The case is particularly interesting since it shows both what the challenges are and how they can be handled.

The rest of this paper is organised as follows. Section 2 provides a critical review of existing literature on business models. The subsequent section introduces industrial network theory in order to create a better understanding of the challenges related to changing existing business models. The following part presents the methods used in this paper and then the case description is provided. The next section contains a theoretical and managerial discussion and eventually some conclusions are provided.

\section{An exposition of the business model literature}

As stated previously, business models have received more attention over the last decade. The concept emerged during the dotcom-bubble and consequently lost a lot of credibility when the bubble burst (Magretta, 2002). Ever since, business models have become more important and last year, Long Range Planning devoted a Special Issue to the topic.

There are several definitions of the business model which are similar, albeit not identical. It has been described as a concept which focuses on 'the architecture of revenue' and the notions of value creation and appropriation (Chesbrough and Rosenbloom, 2002). Business models have also been depicted as the value a firm offers to customers, the architecture of the firm, its network of partners and its way of creating, marketing and delivering this value (Osterwalder and Pigneur, 2003). Zott and Amit 
(2008) define the business model as "a structural template that describes the organization of a focal firm's transactions with all of its external constituents in factor and product markets" (p.1).

Amit and Zott (2001) explored the theoretical foundations of the business model construct by studying value creation in e-businesses. They argued that none of the established frameworks in strategic management and entrepreneurship could fully explain this phenomenon. The concepts of value chains, Schumpeterian innovation, the resourcebased view of the firm, interfirm strategic networks and transaction cost economics could only address different parts of how value is created in e-businesses. Amit and Zott therefore claimed that the business model can be regarded as a more holistic perspective on strategy and value creation which draws upon these bodies of literature.

A growing body of the literature has explored the area of business model innovation in detail (e.g. Charitou, 2001; Markides, 1997, 1998). A business model innovation can be defined as a reformulation of what an existing product or service is and how it is provided to the customer (Markides, 2006). Several scholars have pointed out the importance of renewing the business model, both in order to compete in mature industries and to appropriate the returns from a product innovation (e.g. Chesbrough and Rosenbloom, 2002; Magretta, 2002; Zott and Amit, 2008). Others have suggested that changing the business model is particularly important when launching an innovation of a more discontinuous nature. For instance, both Christensen (2006) and Doz and Kosonen (in print) argued that succeeding with disruptive innovation is a business model challenge rather than a technological problem.

\subsection{Enablers and disablers of business model renewal}

While the importance of renewing existing business models seems to have become increasingly clear to both practitioners and scholars, firms still struggle when trying to do so (Chesbrough, 2009). The literature on business models provides some explanations to why this is the case. Christensen (2006) stated that the conflict between the established business model and new initiatives tend to impede business model innovation. Amit and Zott (2001) offered a similar explanation when arguing that several of the key components of a business model such as novelty, lock-in and complementarities tend to be incompatible with a firm's existing resources and capabilities. Attempts to reconfigure an established business model would therefore be met with a lot of resistance in a firm. Other scholars have pointed out cognitive delimitations among senior managers as a source of inertia (Chesbrough and Rosenbloom, 2002; Tripsas and Gavetti, 2001).

For sure, the above-mentioned work has contributed to an increased understanding of the challenges related to changing established business models. However, none of the explanations put forward are specific for business models. In fact, similar arguments have been put forward in the product innovation and technology management literature for a long time. The explanations which focused on incompatibility and tension between old and new business models are analogous with for instance the argument that new technologies may render existing competencies and organisational structures obsolete and therefore cause problems for incumbent firms (Henderson and Clark, 1990; Tushman and Anderson, 1986). Moreover, cognitive barriers are not specific for business models. Rather, they may impede any kind of organisational renewal or product development efforts (Prahalad and Bettis, 1995). Hence, existing literature has not really identified the specific challenges related to business model renewal. Given that firms seem to succeed 
with product innovation more often than with business model renewal, these challenges must either be similar, albeit of a different magnitude or fundamentally different in some way. Such different explanations have not really been identified by the previous literature.

Partly as a consequence of a lack of identified unique business model challenges, the literature on how business models can be renewed is also similar to the solutions offered in other fields of management theory. For instance, Chesbrough (2009) suggested that experimentation, effectuation and organisational leadership may help firms to change their business models. These managerial prescriptions are not specific for business models. Veryzer (1998) claimed that the new product development process is more experimental and open-ended for initiatives of a more discontinuous or radical nature. Effectuation, as opposed to causation, refers to the process of changing the environment by taking action without knowing the outcome, instead of analysing and trying to control the future (Sarasvathy, 2001). Sarasvathy argued that a key characteristic of entrepreneurial behaviour is to pursue effectuation rather than causation. This notion may offer some guidelines for how to go about when renewing a business model, but it is not specific for business models. The same holds for organisational leadership which has been identified previously as crucial in order to succeed with major changes (e.g. Rosenbloom, 2000). Doz and Kosonen (in print) provided further insight into how firms can change their business models when underlining the importance of strategic agility in terms of adapting to the environment and being able to allocate resources to new models. Again, these prescriptions are well elaborated and relevant to managers, but not unique for business models.

Summing up, there seems to be a gap in the business model literature. Several scholars have pointed out that firms often succeed with product innovations but fail to change their business models accordingly. However, the theoretical review above suggests that the literature both on barriers and on enablers of business model renewal resembles previous literature on new product development and organisational change in general. Given that it seems to be more difficult to change a business model, we should expect the challenges and managerial solutions to be unique in some way. This paper seeks to identify these business model specific challenges and managerial solutions. Section 2.2 provides some further elaboration on the business model notion and introduces industrial network theory as a way to approach these issues.

\subsection{Business models and industrial networks}

Zott and Amit (2010) provide a conceptualisation of business models as "a system of interdependent activities that transcends the focal firm and spans its boundaries". This definition is particularly interesting because unlike other depictions, it underlines the interconnected nature of business models. In this sense, business model initiatives are different from the development of new products, which is more of an internal, firmspecific challenge. For sure, product innovation efforts also depend upon linkages with the external environment, for instance when it comes to purchasing critical components. But business models are explicitly concerned with how value is created and captured from actors beyond the boundaries of the firm. The notion of interdependence has up until now been mentioned in the literature on business models, but not addressed in further detail. Pynnonen et al. (2008) present an exception to this pattern by drawing upon theory on value networks when analysing business models. We adopt a similar 
approach but focus more explicitly on the interdependent nature of business models. To understand this issue, a more detailed description of industrial networks is provided below.

Since the 1980s, the industrial network approach to business-to-business relationships has received increased interest (Håkansson, 1982). Proponents of this perspective claimed that the previous literature missed out on the interdependence that characterises relations between suppliers and customers. This perspective originated from a criticism of neoclassical economic theory and the notion of homogeneous customers. These scholars argued that a market consists of actors that are interrelated and depend upon each other. Therefore, the term 'network' is often used instead of 'markets', thus underlining the mutual dependence among suppliers and customers (Håkansson, 1989). In this sense, the network concept differs from the traditional dichotomy of markets and hierarchies.

When studying the interaction between firms, network scholars regard companies as actors which employ resources in order to perform certain activities. Firms can be regarded as actors, but individuals and groups can also be thought of as actors. They have different aims, scale and scope and are embedded in a network. Actors perform activities by transforming resources and making transactions with other constituents (Håkansson and Snehota, 1995). It is assumed that no single actor can command all resources or perform all activities throughout a network and therefore, they are interrelated with other resources and activities. Therefore, actors depend upon the environment, which is in turn regarded as unreliable. In order to remove this uncertainty, they tend to build relationships with other actors (Dubois, 1998) and thus become interdependent. Networks are held together by mutual benefits, but there is always a mixture of intersecting and diverging interests in these relationships (Håkansson, 1989). Industrial networks are therefore based upon restricted freedom (Ford et al., 2003). This approach has a lot in common with resource-dependent theory (Pfeffer and Salancik, 1978), which states that organisations are to a large extent controlled by others since they obtain resources from their environment.

The above-mentioned interdependence implies that a firm's behaviour is largely governed by actors beyond its own boundaries. This observation has several implications for attempts to change existing business models. Given that firms are interdependent the main managerial challenge is not a matter of resource allocation, but rather how relations with other actors can be handled. In this respect, business model renewal is something fundamentally different from product innovation since firms depend upon actors that they cannot control to the same extent. While a firm's relations are the basis of its current success, these relations may at the same time impede attempts to change its business model since networks are conservative to their nature (Håkansson and Ford, 2002). Moreover, the industrial network approach suggests that a network needs to be mapped and analysed in order to understand barriers and enablers of business model renewal. We discuss how this can be done in the Section 5.

\section{Method and research setting}

Along with a more theoretical discussion, this paper is based upon an exploratory single case study, which examines how the studied firm developed, launched and eventually succeeded with a product innovation that required a new business model. According to Eisenhardt (1989), a case study is the appropriate research strategy when little is known 
about a phenomenon and current perspectives seem inadequate. As stated previously, the business model concept is still relatively new. Furthermore, the theoretical review above identified a couple of issues that have not been sufficiently understood yet. Therefore, we believe that an exploratory case study is a suitable method for addressing specific challenges and managerial solutions related to business model renewal. This method generates the kind of detailed description that is needed in order to explore an issue that needs to be further addressed (Yin, 1994).

Single case studies imply a limited generalisability of the findings (Eisenhardt, 1989). However, as the work presented aims to develop new theory rather than testing existing theory, the method is deemed to be suitable. Thus, this paper does not attempt to provide an exhaustive set of answers, but rather to identify some specific challenges and how they can be handled. Moreover, the case study approach enables a rich and nuanced description which is often required in order to understand the above-mentioned topic. The authors decided to base the case study upon interview data since this source of evidence generates a nuanced and insightful depiction. According to Yin (1994), interviews may result in a biased description and interpretation of events. This potential weakness was handled by targeting many interviewees and by performing the interviews by a duo of researchers. All the interviews were recorded, transcribed and listened to afterwards.

In total, nine employees were interviewed two times, which may seem to be a low number. However, according to Yin (1994) interviews can be quite focused and directly address the topic, hence enabling a rich understanding quite rapidly. Moreover, the interviewees had different roles and insights into the project - six of them worked in the R\&D department, either as directors or senior engineers with plenty of experience. The other three persons had been in charge of business development activities related to the studied innovation. Hence, a relatively small sample of interviews could still cover several different aspects of the project. They were targeted with semi-structured questionnaires, asking the respondents to describe the development of the product, what the main difficulties were and how the product could eventually be turned into a commercial success by renewing the business model. Several interviews were conducted with the person who was in charge of changing the business model. Follow-up interviews were also performed in order to ensure an accurate interpretation of the gathered information. The case study description below emerged from similarities in the responses from the interviewees. It was also read and validated by the innovation manager and the person who had been in charge of the main business model changes that this product had implied. After the termination of the project, a final presentation was given to the company where the main findings and conclusions were communicated. During this session, the general interpretation of the collected data could be validated one more time. Hence, the empirical description in this paper emerged from an iterative approach where the findings have been validated at several points in time.

The present authors maintained a formal research partnership with the studied firm throughout the study and were interacting with it continuously during 2007-2008. This relationship enabled extensive access both to databases and to key employees. Within the scope of this partnership, scorecards have also been sent out regarding the creative climate at the company and the innovative capabilities of the firm. In total, more than 150 people answered these scorecards, giving a total response rate of more than $70 \%$. This was done as part of an innovation audit that was performed at the firm. During the audit, the interviews were conducted with top and middle management. Moreover, detailed case studies of nine discontinuous innovation projects at the firm have been done within the 
scope of the research which this paper is based upon. These data should be regarded as important background knowledge for the study described in this paper.

\section{Results}

The studied product innovation is a diaper for adults, intended to take care of heavy incontinence among elderly people. The product was launched by a company which has been a global player in the personal care industry for several decades, manufacturing diapers, feminine pads and incontinence products. The firm pioneered the incontinence market in the 1970s and is a dominant actor in this business today. Over the years, the company has sought to sustain its leading position by launching innovative incontinence products, whereas it has remained a follower in the diaper and feminine pad markets. Incontinence products are both sold to end-consumers and to retirement homes. The studied product is only sold to retirement homes.

The incontinence diaper was first launched in 2001 and then re-launched in 2002. The technical development started ten years earlier within a concept development project. Initially, the scope was more open, with the purpose of generating new knowledge rather than aiming for a new product. This development eventually resulted in an ambition to launch a new incontinence product, which would be based upon a belt, instead of having a pant diaper or using tape when attaching it. There were several technological challenges in the project. A belt had to be developed, and by that time, belts were rarely used in incontinence products. Moreover, both the absorption core and the shell of the diaper had to be improved.

The first attempt to commercialise the innovation took place in 1994. New machines were built and this was done at the same time as the product was developed due to strong pressure from management. Eventually, this development turned out to be very expensive and it increased the complexity of the project significantly. Therefore, the project was put on hold for some years, but since the firm's products for heavy incontinence became increasingly subject to price competition, the firm decided to re-start the development activities in the late 1990s and thereby replace the 'all-in-one' diaper the firm had been selling previously. 'There was a strong commitment from an early point; management really believed that new products had to be developed in order to survive in the long term', one project manager recalls. This time the technological ambitions were lowered. Instead of using a belt, it was decided that the product should be attached with tape, since this would be cheaper. When the product was launched in 2001 it turned out that this tape made the diaper too stiff and very uncomfortable to wear. Therefore, it had to be withdrawn from the market and the brand was severely damaged.

\subsection{Barriers to adoption}

Despite this failure, management still believed in the product and therefore decided to improve the belt and re-launch it in 2002. Once the diaper had been put on the market again, the sales did not take off, for several reasons. The new design made the product appear inferior, though it was in fact much better, both in terms of absorption capacity and in terms of convenience for the users. More importantly, the price was higher, and thus it was difficult for the sales organisation to justify to the purchasers at retirement homes why they should buy it. Previously, the firm had mainly offered products which 
could last longer, thereby lowering the customer's expenses. Though the new product resulted in an improvement along this performance dimension, the main difference was that it enabled cost reductions by decreasing the total cost of incontinence care. The 'consequence costs' in terms of unnecessary product consumption, extra work, laundry and skin treatments could be reduced significantly. Up to $10 \%$ of the total cost could be removed, and since the cost of incontinence products only summed to $1 \%$ of the total incontinence care cost, this reduction was indeed remarkable and would easily justify a higher price. The main reason for this reduced incontinence care cost was that problems with skin irritation and leakages could be decreased. This improvement was primarily related to the breathable back sheet which enabled air to circulate instead of having the fluid circulating. The back sheet thus helped to maintain a healthier skin while at the same time increasing the comfort.

Hence, the new product resulted in fewer pad changes, less leakage and skin breakdowns and this lead to a significant reduction of the total incontinence care cost. But since the purchasers at retirement homes were not assigned to handle the total cost of incontinence care but only the costs of incontinence products, they had in fact low incentives to buy this innovation, despite its superior performance. Moreover, the sales organisation preferred to sell the old products since they did not know how to justify the higher price. Thus, the incentives both to buy and to sell the product were initially very low. It also proved difficult for the caregivers to understand how the product should be used. The innovation was easier and more convenient to put on, but how to do so was not obvious, and therefore the product was not really appreciated by the caregivers either, despite being more ergonomic when used correctly.

To sum up, even though the innovation offered increased convenience both for users of the product and for the caregivers, while at the same time creating significant cost reductions for retirement homes, the product was about to become a failure. 'We underestimated the barriers to success and therefore the product was initially a commercial failure', one engineer recalls.

\subsection{Business model renewal}

Despite all the difficulties related to this product, the firm still believed in it since the diaper clearly created an increased economic value for the customer. Therefore, the company started to look for new ways of selling it, by focusing on different attributes and sales channels. One major step in this direction was the launch of a service organisation which aimed to take a broader perspective on sales, focusing on total incontinence care rather than just selling products. This can be illustrated by the motto of the organisation, which is 'better care at a lower total cost'. The new unit sought to communicate these values by performing studies together with customers, which showed the superior performance of the innovation. In one study together with six Danish municipalities, it was proven that the customer's total cost for products could be reduced by $22 \%$ and that leakages could be reduced from $25 \%$ to $10.6 \%$. In another study, they focused on the total cost of incontinence management, illustrating that it could be reduced by $13 \%$. Moreover, by using simulations, the service organisation showed to the customers how the 'hidden' costs of incontinence in terms of leakages, the required time for pad changes and skin breakdowns could be reduced significantly.

Apart from focusing on new performance attributes and changing the value proposition, the firm started to work actively with educating caregivers regarding how to 
use the product. The innovation manager said that "it was not really intuitive how the product should be put on, but once we showed the caregivers how it is done they found it to be much more convenient than to use the old products".

The service organisation also performed a study together with Linköping University, where they could show that the innovation was in fact much more ergonomic for the caregivers. This was an entirely new performance dimension for an incontinence product that the firm was scarcely aware of when the product was first launched, even though this had been a focus area in the development ten years earlier. This attribute implied that the costs related to employee absence due to illness could be reduced, thus lowering the total cost of incontinence care even further. Once these studies had been performed, the sales force felt more confident selling the product. Furthermore, the incentives of the sales organisation were changed so that the employees received their annual bonus based upon how much they sold of the new product.

The sales channel was also shifted towards the management of retirement homes, since they could focus on total incontinence care costs rather than solely the costs for the products. By using advanced statistics and computer simulations, and extending the value proposition, it was proven that the innovation decreased the total cost of incontinence care significantly, and this argument turned out to be more appealing to the managers than to the purchasers.

After having taken these measures, sales eventually started to take off and have been growing in recent years. The innovation manager summarised the story by saying that "the product would not have become a commercial success if a service organisation had not been created and the sales approach had not been changed". Moreover, top management had been firmly committed and was not reluctant to cannibalise upon previous products, primarily because the profitability was much higher on the new product.

\section{Analysis and discussion}

The case description above provides further evidence on the necessity of changing a business model when introducing a product that brings new performance attributes to the market (Christensen, 2006). The studied incontinence diaper created an increased utility for the customer, but did not succeed until the business model was changed. This section provides a theoretical and managerial discussion of business model renewal and synthesises the case with the previously described literature on business models and industrial networks.

\subsection{Challenges related to business model renewal}

The literature reviewed in this paper suggested that while several challenges related to changing a business model have been identified, they are not really specific for business models. Indeed, many of them were of a rather general nature and are familiar to scholars in strategic management, entrepreneurship and new product development. The development and eventual success of the studied incontinence diaper shed some new light on how the business model innovation challenges differ from those related to product innovation. 
Starting with the actual product development, it can be seen in the case study that the main challenges were related to patience and being determined to allocate resources to a project that turned out to be very problematic. Hence, the issue was a matter of execution where top management continued to believe in the project, despite the difficulties. As it was stated in the case description, this commitment was a key success factor.

Once the product was launched, the firm faced the challenge of appropriating the returns from the created value and changing the business model in order to do so. These challenges were of a fundamentally different nature than those related to developing the product. The product's success in the marketplace could not be controlled in the same way as the development activities. Zott and Amit (2010) suggested that the business model can be regarded as a construct which is based upon interdependence. This definition helps us to understand why business model renewal seems to be so difficult. The case illustrates how several barriers to adoption occurred due to this interconnectedness since the product was incompatible with the existing network constellation of actors, resources and activities. The product required a shift in the activity of changing the diapers. Moreover, the increased value that the product generated was distributed differently. It was spread over the end-users in terms of convenience and reduced skin irritation, the caregivers because the product was much more ergonomic and the retirement homes by offering a significant cost reduction for total incontinence care. However, the individual purchaser was not assigned to take this value creation into consideration, and this in combination with the higher price per unit created an adoption barrier.

Clearly, these challenges are different from the ones related to developing the product, which were primarily related to the top management commitment and experimentation. Drawing upon the industrial network theory outlined previously, we therefore suggest that the challenges which are unique to renewing a business model are related to interdependence and systemic changes in the way that value is created and distributed among the key actors. A firm's existing business model is not only controlled by the firm itself, but also by the incentive structure of its surrounding stakeholders, which are beyond direct managerial control. A product which requires a change in the activities, relationships or implies a new distribution of value will meet resistance. As stated before, firms build networks and relationships in order to reduce uncertainty, but as a consequence, they also become subject to limited freedom (Ford et al., 2002) which hampers its attempts to change established business models.

It should be underlined that the case study above concerned a relatively minor shift in a dyadic relationship between a supplier and a customer. A product innovation with some new performance attributes was enough to create systemic changes and resistance inside the customer's organisation. Changing a business model which affects several actors throughout an entire supply chain is therefore likely to be even more difficult. In such a context, an attempt to reconfigure a business model may affect several functions in many firms and due to the aforementioned interdependence, it is enough that one actor blocks the initiative for it to fail (Adner, 2006). As firms are to a larger extent drawing upon external sources in order to innovate and become more interconnected (Chesbrough, 2003), these difficulties will probably increase over time. Bearing this in mind, it becomes easier to understand why many firms struggle to renew their business models. 


\subsection{Managing business model renewal}

The notion that business models are built upon interdependence also reveals how firms can succeed when trying to change their business models. First of all, we observe that the managerial prescriptions related to business model renewal seem to be more applicable to the product development phase in the case description above. Chesbrough (2009) suggested that experimentation, organisational leadership and effectuation were some of the determinants in succeeding with changing a business model. When developing the product, the firm experimented extensively with new concepts and technologies. Moreover, the engineers tried to use their skills in order to reach a goal which was not known beforehand as suggested by Sarasvathy's (2001) notion of effectuation. It is also clear that top management demonstrated organisational leadership is being committed to a project that turned out to be problematic.

These three factors seem to have been less important in succeeding with the actual reconfiguration of the established business model. Given that the success of the incontinence diaper depended upon changes which were beyond the direct control of the firm it had to find ways to align incentives in favour of the innovation. Under conditions of interdependence, leadership, experimentation and effectuation are important, albeit not sufficient criteria for success since the outcome is in fact governed by actors which cannot be managed by using executive power.

The case study provides some evidence regarding how firms can renew their business models. When sales did not take off, the firm sought to understand how all the relevant actors and activities were affected by the new product. A couple of barriers were found, such as the discrepancy between the purchaser's incentives and the overall utility of the retirement homes and the caregiver's lack of knowledge regarding how the product should be used.

Once these actors and their incentives had been identified, the firm sought to develop a business model that was compatible with this structure. Under conditions of restricted freedom (Ford et al., 2002), firms depend upon its surrounding environment and therefore need to map and align incentives in order to succeed. The studied firm did so by undertaking a couple of measures. Given that the new incontinence diaper created value on a more systemic level for the customer by reducing the total cost, the firm targeted the management of retirement homes rather than the individual purchaser. When doing so, the value proposition was also changed from selling incontinence products towards offering 'better care at a lower total cost'. Moreover, given that the activity of changing diapers had to be altered, the firm started to educate caregivers regarding how the product should be used (Table 1).

Summing up the above, our findings provide some tentative guidelines for how firms can go about when trying to renew their business models. As stated in the theoretical review, some authors have pointed out the interdependent nature of business models, but little is known about how firms can change their business models under conditions of restricted freedom. From this theoretical standpoint, we have contributed to the existing literature by pointing out some guidelines as to how firms can renew their business models. 
Table 1 Some managerial guidelines for how firms can renew their business models

\begin{tabular}{lll}
\hline \multicolumn{1}{c}{ Managerial action } & What was done in the studied case \\
\hline Step 1 & $\begin{array}{l}\text { Map all relevant actors in terms of } \\
\text { their incentives, resources and } \\
\text { activities }\end{array}$ & $\begin{array}{l}\text { The incentives of purchasers were not compatible } \\
\text { with the new diaper. The product required that the } \\
\text { caregivers changed their activity of changing diapers } \\
\text { The product created value for the organisation on a } \\
\text { more systemic level - the total cost was lower }\end{array}$ \\
$\begin{array}{lll}\text { Find out how value is created and } \\
\text { distributed among these actors }\end{array}$ & $\begin{array}{l}\text { while the unit price was higher } \\
\text { Step } 3\end{array}$ \\
$\begin{array}{l}\text { Identify actors which are critical for } \\
\text { the adoption of the product } \\
\text { innovation }\end{array}$ & $\begin{array}{l}\text { Manvent of retirement homes needed to be } \\
\text { into consideration. Caregivers had to be re-educated }\end{array}$ \\
Step $4 \begin{array}{l}\text { Design a business model which } \\
\text { aligns incentives throughout the } \\
\text { established actor network }\end{array}$ & $\begin{array}{l}\text { The value proposition was changed to 'better } \\
\text { incontinence care at a lower total cost' and } \\
\text { management was targeted instead of individual } \\
\text { purchasers. Caregivers were re-educated and a closer } \\
\text { relation to customers was developed }\end{array}$ \\
\hline
\end{tabular}

Note: The middle column is on a generic level and the right hand column describes how it was accomplished in the studied case.

Companies need first of all to identify all actors, resources and activities which are affected or can influence the adoption of a product. It should be pointed out here that those actors can be found inside the customer's organisation as well as in other parts of the firm's network. Second, the incentives that govern these actors must be mapped and understood. These conditions are more or less fixed and finding the right business model is a matter of figuring out how these incentives can be aligned in favour of the product, for instance by helping actors to change their activities or by targeting new actors with a new value proposition.

\section{Conclusion and future research}

We started this paper by observing that while many firms are good at introducing new products, they often fail to renew their business models. Several scholars have pointed out the importance of changing existing business models in order to succeed with product innovations, especially those of a more discontinuous nature (Christensen, 2006). However, more knowledge is needed regarding why this seems to be so difficult and how firms can go about when changing their business models. We have tried to address these two issues by drawing upon industrial network theory and by using an illustrative case study. Our literature review suggested that most of the literature about business model renewal is of a general nature and does not really make a difference between business models and new products. Given that it seems to be more difficult to change a business model than a product, we have tried to identify in what ways these challenges are different, and how they can be handled.

Having paid special attention to Zott and Amit's (2010) definition of business models as being based upon interdependence we went into further detail using industrial network theory. Based upon our case study and theoretical review, we conclude that business models are difficult to reconfigure since such a change depends upon actors outside the firm's boundaries and thus, only a limited control can be imposed. One reason why it 
seems to be easier to introduce new products than new business models would therefore be that a firm has much more control over new product development efforts than business models, which to some extent transcend the boundaries of the firm.

A couple of guidelines regarding how the dilemma of interdependence can be handled have also been presented. To renew a business model, firms need to identify all affected actors and activities as well as their incentives. Based upon this input, firms can develop new business models by targeting new actors, encouraging changes in existing activities and aligning incentives throughout the network.

Having drawn upon one single case study and some theory on industrial networks, our conclusions need to be further validated. We therefore encourage other scholars to explore and test our findings, particularly by looking at business model changes throughout entire supply chains. These challenges are likely to be even more complex and difficult to handle since more actors are affected in such a setting.

\section{References}

Amit, W.J. and Zott, C. (2001) 'Value creation in e-business', Strategic Management Journal, Vol. 22, Nos. 6-7, pp.493-520.

Charitou, C. (2001) 'The response of established firms to disruptive strategic innovation: empirical evidence from Europe and North America', PhD Dissertation, London, UK: London Business School.

Chesbrough, H. (2009) 'Business model innovation: opportunities and barriers', Long Range Planning.

Chesbrough, H. (2003) Open Innovation: The New Imperative for Creating and Profiting from Technology. Boston, MA:, Harvard Business School Press.

Chesbrough, H. and Rosenbloom, R. (2002) 'The role of the business model in capturing value from innovation: evidence from Xerox corporation's technology spin-off companies', Industrial and Corporate Change, Vol. 5, No. 4, pp.1143-1180.

Chesbrough, H. (2010) 'Business model innovation: opportunities and barriers', Long Range Planning, Vol. 43, Nos. 2-3, pp.354-363.

Christensen, C.M. (1997) The Innovator's Dilemma. Cambridge, MA: Harvard Business School Press.

Christensen, C.M. and Raynor, M.E. (2003) The Innovator's Solution, Creating and Sustaining Successful Growth. Cambridge, MA: Harvard Business School Press.

Christensen, C.M. (2006) 'The ongoing process of building a theory of disruption', Journal of Product Innovation Management, Vol. 23, pp.39-55.

Doz, Y.L. and Kosonen, M. (in print) 'Embedding strategic agility: a leadership agenda for accelerating business model renewal', Long Range Planning.

Doz, Y.L. and Kosonen, M. (2010) 'Embedding strategic agility: a leadership agenda for accelerating business model renewal', Long Range Planning, Vol. 43, Nos. 2-3, pp.370-382.

Dubois, A. (1998) Organizing Industrial Activities Across Firm Boundaries. London: Routledge.

Eisenhardt, K.M. (1989) 'Building theories from case research', The Academy of Management Review, Vol. 14, No. 4, pp.532-550.

Ford, D., Berton, P., Brown, S., Gadde, L.E., Håkansson, H., Naude, P., Ritter, T. and Snehota, I. (2002) 'The business marketing course', Managing in Complex Networks. Wiley: Chichester.

Ford, D., Gadde, L.E., Håkansson, H. and Snehota, I. (2003) 'Managing networks', in D. Ford, L-E. Gadde, H. Håkansson and I. Snehota (Eds.), Managing Business Relationships. New York: Wiley. 
Håkansson, H. (Ed.) (1982) International Marketing and Purchasing of Industrial Goods. An Interaction Approach. London: Routledge.

Håkansson, H. (1989) 'Corporate technological behaviour', Cooperation and Networks. London: Routledge.

Håkansson, H. and Ford, D. (2002) 'How should companies interact in business networks?', Journal of Business Research, Vol. 55, No. 2.

Håkansson, H. and Snehota, I. (Eds.) (1995) Developing Relationships in Business Networks. London: Routledge.

Henderson, R. and Clark, C. (1990) 'Architectural innovation: the reconfiguration of existing product technologies and the failures of established firms', Administrative Science Quarterly, Vol. 35, No. 1, Special Issue; Technology, Organizations, and Innovation, pp.9-30.

Magretta, J. (2002) 'Why business models matter', Harvard Business Review, Vol. 80, pp.86-92.

Markides, C. (1997) 'Strategic innovation', Sloan Management Review, Vol. 38, No. 3, pp.9-23.

Markides, C. (1998) 'Strategic innovation in established companies', Sloan Management Review, Vol. 39, No. 3, pp.31-42.

Markides, C. (2006) 'Disruptive innovation: in need of better theory', Journal of Product Innovation Management, Vol. 23, pp.19-25.

Osterwalder, A. and Pigneur, Y. (2003) 'An ontology for e-business models', in W. Currie (Ed.), Value Creation from E-business Models. Newton, MA: Butterworth-Heinemann.

Pfeffer, J. and Salancik, G.R. (1978) The External Control of Organizations: A Resource Dependence Perspective. New York: Harper \& Row.

Prahalad, C.K. and Bettis, R. (1995) 'The dominant logic: retrospective and extension', Strategic Management Journal, Vol. 16, No. 1, p.5e14.

Pynnonen, M., Hallikas, J. and Savolainen, P. (2008) 'Mapping business: value stream-based analysis of business models and resources in information and communications technology service business', Int. J. Business and Systems Research, Vol. 2, No. 3, pp.305-323.

Rosenbloom, R.S. (2000) 'Leadership capabilities and techno- logical change: the transformation of NCR in the electronic era', Strategic Management Journal, Vol. 21, pp.1083-1103.

Sarasvathy, S. (2001) 'Causation and effectuation: toward a theoretical shift from economic inevitability to entrepreneurial contingency', The Academy of Management Review, Vol. 26, No. 2, pp.243-263.

Teece, D. (2010) 'Business models, business strategy and innovation', Long Range Planning, Vol. 43, Nos. 2-3, pp.172-194.

Tripsas, M. and Gavetti, G. (2001) 'Cognition, capabilities and inertia: evidence from digital imaging', Strategic Management Journal, Vol. 21, Nos. 10/11, Special Issue: The Evolution of Firm Capabilities, pp.1147-1161.

Tushman, M. and Anderson (1986) 'Technological discontinuities and organizational environments', Administrative Science Quarterly, Vol. 31, pp.439-465.

Veryzer, R.W. (1998) 'Discontinuous innovation and the new product development process', Journal of Product Innovation Management, Vol. 15, pp.304-321.

Yin, R. (1994) Case Study Research Design and Methods. Applied Social Science Methods Series, Vol. 5. New York: Sage Publications.

Zott, C. and Amit, R. (2010) 'Business model design: an activity system perspective', Long Range Planning, Vol. 43, Nos. 2-3, pp.216-226 (Business Models).

Zott, C. and Amit, R. (2008) 'The fit between product market strategy and business model: implications for firm performance', Strategic Management Journal, Vol. 29, pp.1-26. 